\title{
Communication for Social Mobilization: An Evaluative Study of the National Immunization Campaign in Nigeria
}

\author{
Grade Imoh Ph.D. \\ Department Of Mass Communication, Delta State University, Abraka, Delta State, Nigeria.
}

\begin{abstract}
This study critically evaluates the communication strategies used in the campaign for social mobilization for the National Programme on Immunization in Nigeria. Its objective is to determine the communication factors that contributed to the participation of individuals and groups in the programme at the federal, state and local government levels. Fifty four (54,) subjects, consisting of 5 policy and decision makers in health, information and education sectors, 5 community leaders, 15 media personnel, 15 state health officials, 20 LGA officials, 12 representatives of non-governmental organizations, 5 opinion leaders, 7 clinic staff, 6 state health officials and 8 mothers were purposively selected from the federal level and two states; Imo and Kano states of Nigeria. Methodology used for data collection includes individual and group interviews and critical evaluation instruments. Findings show that the mass campaign strategy proved to be the most effective strategy for reaching both rural and urban dwellers and specific groups with immunization messages. The alliance between the health workers and community leaders, social groups, NGOs and the information education sectors, had a multiplier effect on the campaign and helped to create feelings of solidarity. The ubiquitous channels of traditional and religious leaders and youth groups helped to spread immunization messages and gain support for the programme. Women and women groups were adequately involved at the federal level and in Imo State, a Christian state in the South-East. This was not the case in Kano State, a muslim state in the north due to sociocuitural factors. The sustainability of the programme lies in more integration, more intersectoral collaboration, more institutionalization, more quality verification, more decentralization, greater local political commitment and a multistrategic approach to campaign planning and implementation.
\end{abstract}

Keywords: Communication for child survival, childhood immunization, social mobilization.

\section{Introduction}

Available records suggest that, in the absence of immunization, approximately 216,000 Nigerian children will die each year, an average of about 600 daily. Of these, an additional 100,000 will be disabled. Measles in particular is a major public health problem with an estimated 3.6 million cases occurring annually resulting in about 108,000 deaths and 54,000 disabled (UNICEF 1985). Presently, Nigeria is one of the few countries on earth where the wild polio virus is still endemic. Against this background, the Nigerian government embarked on the Expanded Programme on Immunization (EPI) in 1975, with assistance from the World Health Organization (WHO) and UNICEF. The objective of the programme was to achieve 80 percent coverage of the target population by the year 1990 .

However, there were not enough human and material resources allocated to the programme, political commitment was unreliable, there was lack of effective communication between the policy and decision makers, implementers and users of the programme and coverage remained very low (Imoh, 1991:16).

\section{National Programme on Immunization (NPI)}

In 1999, a new drive by the federal government through the Federal Ministry of Health to sustainably revitalize the immunization system commenced in synergy with the accelerated strategy on polio eradication. Consequently, the federal government established the National Programme on Immunization (NPI), with the mandate to effectively control vaccine preventable diseases through immunization and the provision of vaccines. Key focus was to provide support to the implementation of state and local government area immunization programmes (WHO 2003).

Table 1: Immunization Coverage by Antigen in Nigeria

\begin{tabular}{|l|l|l|}
\hline Antigen & Coverage (\%) & Range (\%) \\
\hline $\mathrm{BCG}$ & 19.3 & $1.58-60.2$ \\
\hline $\mathrm{OPV}_{1}$ & 63 & $23.3-75.6-$ \\
\hline $\mathrm{OPV}_{3}$ & 38.6 & $15.9-59.2$ \\
\hline $\mathrm{DP}_{1}$ & 43.2 & $9.1-73.3$ \\
\hline $\mathrm{DP}_{3}$ & 24.8 & $1.70-49.7$ \\
\hline Measles & 25.3 & $5.5-54$ \\
\hline Fully immunized & 12.7 & $1.3-40.2$ \\
\hline
\end{tabular}

Source: ICS Survey 2003. 
Strategies used for the programme include (i) Routine immunization. (ii) Targeted "mop up" campaigns for polio eradication in the form of door to door immunization of children in focal areas and (iii) Supplementary Immunization Activities (SIAs) in the form of National Immunization Days (NIDS) conducted to rapidly boost immunity of all children under five, regardless of their immunization status. Programmatically, Nigeria has not been able to achieve the coverage targets for Nigeria. (See Table 1). This is because the communication efforts have lagged behind the technical and operational aspects, such that community involvement and participation have been taken for granted (Imoh, 1991:17)

\section{Statement of the Problem}

Past evaluations of the programme have been product oriented, rather than process. They have been based on programme impact and knowledge and behaviour changes in the target population, without recourse to the prevailing socio-cultural, organizational and communication variables. Because of the growing importance of immunization as a global strategy for reducing infant deaths, and the massive human and financial resources allocated to the programme by the federal, state and local governments and donor agencies (WHO, UNICEF, USAID), it is necessary to monitor the process and viability of the communication strategies used in ensuring the involvement and participation of policy and decision makers, community leaders, community groups, media personnel, individuals and families in the programme.

The National Programme on Immunization (NPI) is a people-oriented programme with government support. To create demand for the programme, the support, involvement and participation of mothers with children, as well as policy and decision makers, health workers, professional groups, community leaders and community groups is needed at all levels of implementation. For this reason, the study will focus on the activities of these groups at the federal, state and local levels. In Nigeria, immunization is still voluntary, and its success is still dependent upon voluntary demand. Media messages have been directed at the Nigerian audience to stimulate proper attitudes to immunization (NPI), yet the utilization level has been far short of the target expected. The study therefore focuses on the communication channels and messages used in terms of content, saliency, clarity and relevance, taking audience needs, expectations and constraints into consideration.

About 60-70 percent of Nigerians live in rural areas, where mass media involvement in promotional activities is minimal because of urban bias in location and reach of mass media institutions. What role have the media played in promoting immunization and reaching the isolated rural communities with immunization messages? What actions have the implementers and health workers taken to make immunization messages more effective, salient and user oriented? What interpersonal efforts by extension workers and community groups have been made in order to reach the target population scattered over large geographical areas; some of which are not accessible to mass media messages, outreach operations and static posts? Immunization is a technology and those who handle it need adequate skills so as to be able to demonstrate and explain it to the potential users. To what extent has training equipped health workers and volunteers with technical skills that will enable them inform, convince and mobilize the beneficiaries? Has communication with the people always used the channels most accessible and credible to the people? Have messages addressed fears and doubts of potential users of the programme?

Even though the campaign is initiated and executed by the Ministry of Health, we need more than health workers and government clinics to make the programme succeed. To what extent, has the involvement of the non-health sectors, private sector and community groups been examined both as channels for immunization messages and as sources of material support? Immunization messages will make impact on mothers when they are congruent with the expected meaning of mothers. Has the process of communicating NPI messages included audience research and pretesting of educational and promotional materials and messages before dissemination, to avoid channel and semantic noise?

In the diffusion of innovation, it has been established that the presence of social reinforcing factors can make the difference between intention and performance (Green 1984). The role of the "significant others" within the sociological tradition and the "opinion leaders" within the communication environment in influencing individual immunization behaviour cannot be overemphasized. The study therefore looks at the established patterns of informal communication, social networks of rural communication and the role of influence and social pressure at the individual, family and community levels.

\section{Objectives of the Study}

1. To determine the communication strategies used to ensure the involvement and participation of health workers, NGOs, local groups, opinion leaders, decision makers, families, users and specific groups in the immunization campaign at the federal, state arid local government levels.

2. To determine the steps taken to organize the people and motivate them to act on the new immunization messages they received.

3. To identify the strategies used to identify and reach specific groups at the local level during the campaign. 
4. To identify the gaps in the strategies used in communicating immunization messages to the target population.

\section{Theoretical Basis for Analysis}

Communication for popular participation in large scale programmes is a learning process that requires institutional and operational changes. Green (1984) notes that communication ventures for large scale programmes require for their evaluation, a different set of concepts, methods and procedures which call for a blend of the distinction between strictly psychological and socio-psychological theories, between interpersonal and mass media methods of communication and between inter-organizational and intraorganizational levels of intervention. Consequently, a set of process indicators that reflect institutional and operational changes, such as institutionalization, capacity building and integration informed the design, instrumentation and procedures used for the study.

Backer arid Maiman (1975) identified some modifiable communication processes, such as social pressure, political commitment, organizational and managerial processes, community involvement, intersectoral collaboration, formative research, training, communication channels and media strategies as institutional and operational changes that should be considered in the evaluation of large scale communication ventures.

Case studies of mass campaigns with broad national, state and local support show that the success of the campaign lies on political mobilization as a basis for stimulating widespread reflection and action (Hall 1978). The communication strategy often used, emphasizes mass media, interpersonal and intermediate channels and traditional media. The organizations that coordinate and bear the campaign messages are temporary, but built upon the already existing personnel and resources of many permanent, formal and informal institutions (Rogers 1977).

\section{Methodology} Sample

This study has been conducted at different levels and at different geographical locations in Nigeria.

The study focused on stratified samples of the Nigerian population selected on the basis of religious, cultural and environmental differences. Kano was chosen because of its geographical location in the North, with a predominantly Muslim population of Hausa and Fulani descents, while Imo state was chosen because it is a predominantly christian state in the south, where the Ibos, a major ethnic group in Nigeria reside. This was done to reflect the heterogeneous nature of Nigeria. At the micro level, the sample includes clinic staff in Kano, Owerri, Kazaure and Ideato government owned vaccination centres.

\section{Table 2; Sample for the Study in Kano and Imo States}

\begin{tabular}{|l|l|l|l|}
\hline Sample & Kano & Imo & Total \\
\hline Opinion leaders & 3 & 2 & 5 \\
\hline Policy/Decision makers & 5 & 4 & 9 \\
\hline State Health Officials & 4 & 2 & 6 \\
\hline State Partners in Health (NGOs) & 7 & 5 & 12 \\
\hline Education Sector & 1 & - & 1 \\
\hline Clinic staff & 4 & 3 & 7 \\
\hline LGA officials & 10 & 10 & 20 \\
\hline Media personnel & 9 & 6 & 15 \\
\hline Mothers & 4 & 4 & 8 \\
\hline Total & $\mathbf{4 7}$ & $\mathbf{3 6}$ & $\mathbf{8 3}$ \\
\hline
\end{tabular}

At the macro level, the subjects drawn from Kano state, include the Emirs of Kano and Kazaure, the commissioners for Health and Education, the Chairmen, Kano municipality and Kazuare Local Government Councils, the Sheik of the Islamic School, Kano, the Principal, Adult Literacy Centre, Kano, officials of NTA and Kano Broadcasting Corporation, the Director, Primary Health Care, Kano State, Medical Director, Kano General Hospital, Chief Health Education Officer, Kano State Ministry of Health, the State Partners in Health team comprising representatives of Rotary International, Red Cross, Adult Literacy, Mass Media Personnel, Nigerian Medical Association (NMA) and women organizations. Also included in the sample, were mothers seen at immunization centres in Kano and Kazuare.

In Imo state, the subjects include, the wife of the Governor, the State Commissioner for Health, State NPI Manager and Chief Health Educator, Chairmen of Owerri and Ideato Local Government Areas, LGA Councillors and officials in Owerri and Ideato Local Government Councils, His Royal Highness, Okolochi autonomous community, Parish Priest of Urualla, media chiefs of Imo Broadcasting Corporation, Director, NTA Aba, the General Manager, Imo Newspaper Corporation, Owerri, State Health Officials and Partners in Health team, comprising representatives from the Red Cross, Rotary International, mass media and women organizations, such as Lioness Club and Inner wheel. 


\section{Instrumentation}

Multiple data gathering instruments were used for the study. They include:

i. Indepth Interview Schedules and Group Discussions

ii. Critical Evaluation of media coverage and

iii. Analysis of speeches and reports

\section{Indepth Interview Schedules and Group Discussions}

A total of 83 subjects comprising 5 opinion leaders, 5 policy and decision makers, 7 clinic staff, 5 state health officials, 6 representatives of non-governmental organizations, 20 local government council officials and 15 media personnel were interviewed during the rapid assessment of the programme in Imo and Kano states. Also interviewed were 8 mothers who were present at immunization posts in Kano, Kazaure and Ideato maternal and child health $(\mathrm{MCH})$ clinics.

Table 3: Subgroups for Indepth Interview Schedules and Group Discussions

\begin{tabular}{|l|l|l|l|}
\hline Sample & Kano & Imo & Total \\
\hline Opinion leaders & 3 & 2 & 5 \\
\hline Policy/Decision makers & 3 & 2 & 5 \\
\hline State Health Officials & 2 & 3 & 5 \\
\hline State Partners in Health (NGOs) & 4 & 2 & 6 \\
\hline Education Sector & 7 & 5 & 12 \\
\hline Clinic staff & 4 & 3 & 7 \\
\hline LGA officials & 10 & 10 & 20 \\
\hline Media personnel & 9 & 6 & 15 \\
\hline Mothers & 4 & 4 & 8 \\
\hline Total & $\mathbf{4 6}$ & $\mathbf{3 7}$ & $\mathbf{8 3}$ \\
\hline
\end{tabular}

The opinion leaders, include the traditional and religious leaders, while the policy makers include; the Commissioners for Health and Education involved in the NPI programme, while the decision makers consist of chairmen of local government councils in Kano, Kazaure, Owerri and Ideato. The other subjects listed in Table 3 are as their names imply. As for State Health officials, those interviewed include, the State Director of Primary Health Care and Chief Health Educator, NPI managers and vaccinators. Media personnel include those who work in National Television Authority (NTA), Kano and Owern and radio and print media houses in Kano, Owerri and Aba.

\section{Procedure}

The interviewing team comprised three UNICEF staff and the researcher. The researcher was part of a team that was designated to conduct a rapid assessment of the NPI in Nigeria. Other members of the team include, Ibrahim Jabr and John Richardson from UNICEF headquarters, New York and Affiong Ukpong, UNICEF office, Lagos.

The researcher used open ended unstructured interview schedules to conduct both personal, and group interviews with the subjects to know the roles they played and the mechanisms of their involvement in the immunization campaign. Personal interviews were held with the policy and decision makers, the opinion leaders, the Directors of Primary Health Care, media chiefs, Chief Health Educators and NPI managers. For the other groups, we used the group discussion approach. There was no systematic way for asking questions. However, through note taking and rational observation, the researcher was able to record all the responses given. Among the questions we asked were:

i. How were you involved in the programme by the Ministry of Health?

ii. When and at what level of planning or implementation were you involved?

iii. What were the roles assigned to you?

iv. How did you go about carrying out your assigned duties?

v. What problems did you encounter?

vi. What were your major achievements?

\section{Critical Evaluation}

Television, radio and newspaper coverage of the campaign was critically evaluated. The purpose was to see how far, these media channels integrated NPI messages. Their programmes were examined for content, interest generating capacity, relevance to felt needs, ability to elicit desired responses, generate feedback and reach the intended audiences with clear messages. 


\section{Procedure}

The researcher as a member of the Universal Child Immunization (UCI) evaluation team, visited the NTA stations in Aba and Kano and watched all their programmes on the immunization campaign. We listened to the jingles and discussions by health personnel on television and asked questions. The media personnel and programme producers answered all questions posed by the researcher. Observations were made and notes taken for analysis.

The Imo Broadcasting Corporation Owerri and Kano Broadcasting Corporation were also subjected to study. We listened to their radio broadcasts and programmes on the NPI. The messages were evaluated for content, relevance and clarity, specifically those that relate to the needs of the audiences, whatever and wherever they may be.

\section{Analysis of Speeches and Reports}

The speeches and statements made by policy makers, decision makers, professional groups, donor agencies and non-governmental organizations with regards to the immunization campaign were analyzed. Official Ministry of Health bulletins, newspaper articles, WHO Bulletin, Primary Health Care Newsletter (The Road) and UNICEF State of the World Children Report formed part of the secondary data sources evaluated. Other sources include,reports of training sessions, coverage survey reports and other reports on field work done on NPI in Nigeria. The purpose of the analysis is to see how far, political statements by policy and decision makers have been reflected in community involvement and in the allocation of financial, material and human resources for the campaign.

\section{Results}

1. Channels used to ensure the involvement of health providers, opinion leaders, local groups, local decision makers and families.

\section{Federal Level}

The Federal Ministry of Health working in collaboration with UNICEF and WHO got the state governments, NGOs, health workers and other sectors involved. The states in turn involved the local government areas, other sectors, NGOs and parastatals under them. The local government councils involved their community leaders, council workers, social groups, NGOs, parastatals and the users (mothers).

As Table 4a shows at the federal level, the federal health workers were involved by the Federal Ministry of Health, UNICEF and WHO. The NGOs, community leaders and local decision makers were all involved by the Federal Ministry of Health.

Table 4a: Communication Channels used to ensure the involvement and participation of groups at the Federal level

\begin{tabular}{|c|c|c|c|c|c|c|c|c|c|c|}
\hline \multicolumn{11}{|l|}{ Groups 4} \\
\hline $\begin{array}{l}\text { Federal } \\
\text { Level }\end{array}$ & Launching & Workshop & $\begin{array}{l}\text { Visits } \\
\text { meeting }\end{array}$ & PA.S. & $\begin{array}{l}\text { Official } \\
\text { instruction }\end{array}$ & $\begin{array}{l}\text { Mass } \\
\text { Media }\end{array}$ & Source & Planning & $\begin{array}{l}\text { Decision } \\
\text { Making }\end{array}$ & Implementation \\
\hline $\begin{array}{l}\text { Health } \\
\text { providers }\end{array}$ & $\sqrt{ }$ & $\sqrt{ }$ & $\sqrt{ }$ & & & & $\begin{array}{l}\text { Fed. Ministry } \\
\text { of Health, }\end{array}$ & $\sqrt{ }$ & $\sqrt{ }$ & $\sqrt{ }$ \\
\hline NGOs & $\sqrt{ }$ & $\sqrt{ }$ & $\sqrt{ }$ & & & & UNICEF/WHO & $\sqrt{ }$ & $\sqrt{ }$ & $\sqrt{ }$ \\
\hline \multicolumn{11}{|l|}{$\begin{array}{l}\text { Local } \\
\text { groups } \\
\text { (Youth and } \\
\text { women) }\end{array}$} \\
\hline $\begin{array}{l}\text { Community } \\
\text { leaders }\end{array}$ & $\sqrt{ }$ & & $\sqrt{ }$ & & & & $\begin{array}{l}\text { UNICEF, Fed. } \\
\text { Ministry of } \\
\text { Health }\end{array}$ & & & \\
\hline $\begin{array}{l}\text { Local } \\
\text { decision } \\
\text { makers }\end{array}$ & $\sqrt{ }$ & & $\sqrt{ }$ & & & & UNICEF & & $\sqrt{ }$ & \\
\hline $\begin{array}{l}\text { Media } \\
\text { personnel }\end{array}$ & $\sqrt{ }$ & & $\sqrt{ }$ & & & & $\begin{array}{l}\text { Fed. Ministry } \\
\text { of Health }\end{array}$ & $\sqrt{ }$ & & $\sqrt{ }$ \\
\hline Families & & & & & & $\sqrt{ }$ & & & & $\sqrt{ }$ \\
\hline
\end{tabular}

Both mass media and interpersonal channels were used to reach and involve all the groups at the national level. As Table 4a shows, the channels used at the federal level for various groups are as follows:

Health Providers: Launching, workshops, meetings, posters and brochures.

NGOs: Launching, workshops, meetings.

Local Groups: None

Decision Makers/States: Launching, meetings.

Families: Clinic, posters, mass media. 
Health providers, state government officials, NGOs and decision makers were involved through launchings, workshops, meetings, brochures and posters by the federal government. However, local groups and families were not involved during the launchings. In fact, local groups were not involved at this level. Mothers were however involved through the mass media, posters and health talks at $\mathrm{MCH}$ clinics.

\section{State level}

At the state level, (See Table 4b) both mass media and interpersonal channels were used. All groups, except mothers and community leaders were involved by the state ministry of health. The community leaders (traditional and religious) were involved by the local government council chairmen. Families were also informed by the local government council health workers through outreach with Pubic Address System (PAS) or intermediate communication channels.

Table 4b: Communication Channels used to ensure the involvement and participation of groups at the State Level

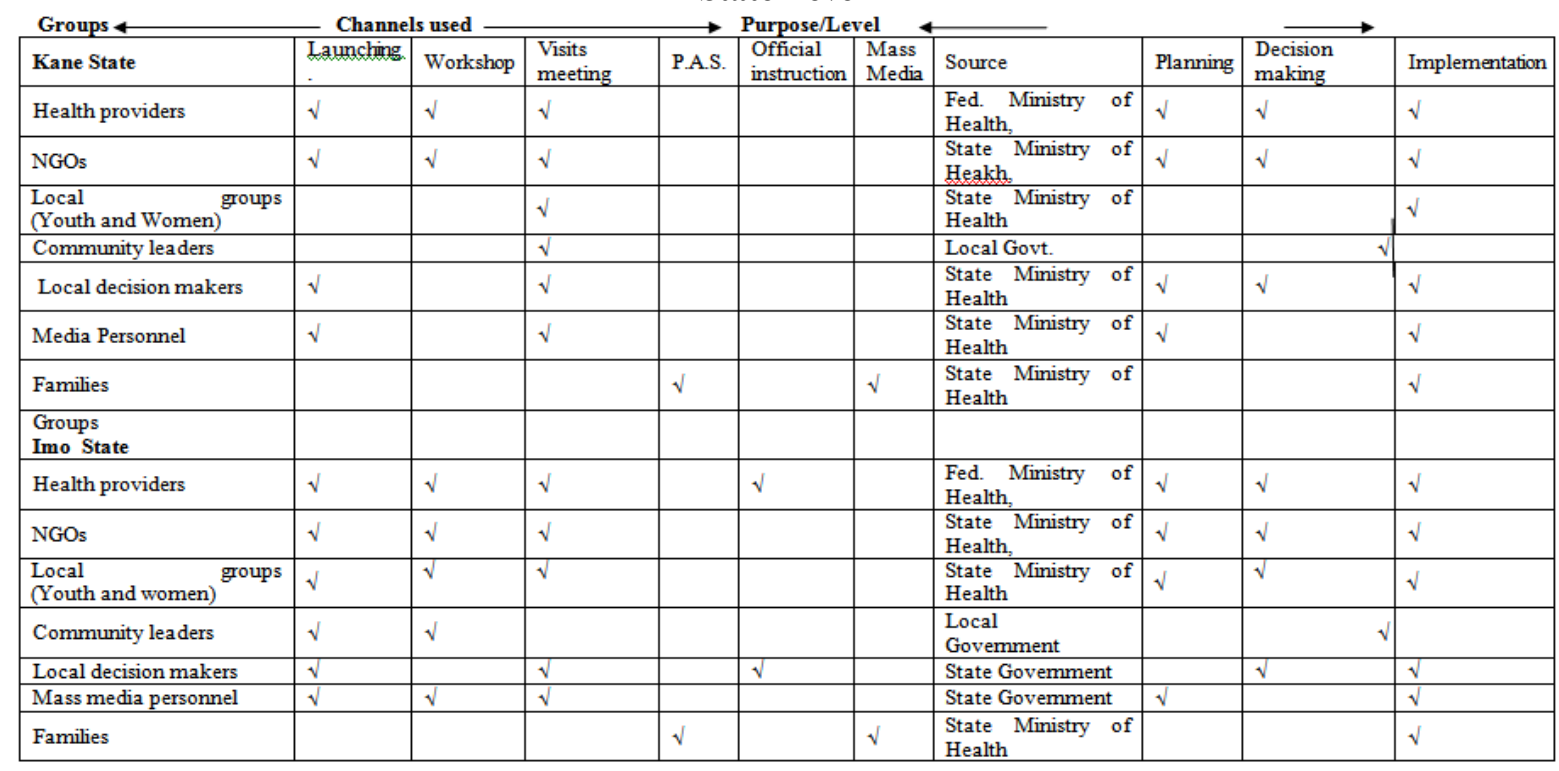

The channels used by the states are further shown below, (See tables $4 \mathrm{~b}$ and $4 \mathrm{c}$ ).

\section{Groups}

Health providers

NGOs

Local groups (Youth/women)

Decision makers(LGA Chairmen)

Religious/Traditional leaders

Families

\section{Channels used}

Launching, workshop, meetings, brochures, posters, letters.

Launching, workshops, meetings, official letters,

Launching, meetings, workshops, official letters.

Launching, meetings, letters

Launching, meetings

Mass media, clinics, posters.

\section{Local Government Areas}

At the local government level, (See Tables $4 \mathrm{c}$ and $4 \mathrm{~d}$ ) there were launchings except in Ideato local government area (Table $4 \mathrm{~d}$. The launchings involved all the community groups except families. As the tables show, the main channels sued for involving community groups were meetings, workshops and official letters. Families were involved more through interpersonal channels than through the mass media. Channels used to involve families include, Clinic health talks, community based education using PAS, Posters and Town Criers.

It is worth noting that there are close similarities between the channels used in Kano and Kazuare local government areas and between Owerri and Ideato local government areas. In the former, most of the groups except families were involved through official letters, $(100 \%)$, while in the latter, meetings and visits were prominent $(50 \%)$. On the other hand, meetings and visits were less frequent $(50 \%)$ in Kano and Kazuare local government areas, while official letters were used to involve $(50 \%)$ the people in Owerri and Ideato local government areas. Workshops were not very prominent at the local government level except in Ideato LGA. This is because all the workshops were meant for the providers only, the community social groups were left out. 
Table 4c :Communication Channels used to ensure the involvement and participation of groups at the Local Government Level in Kano State

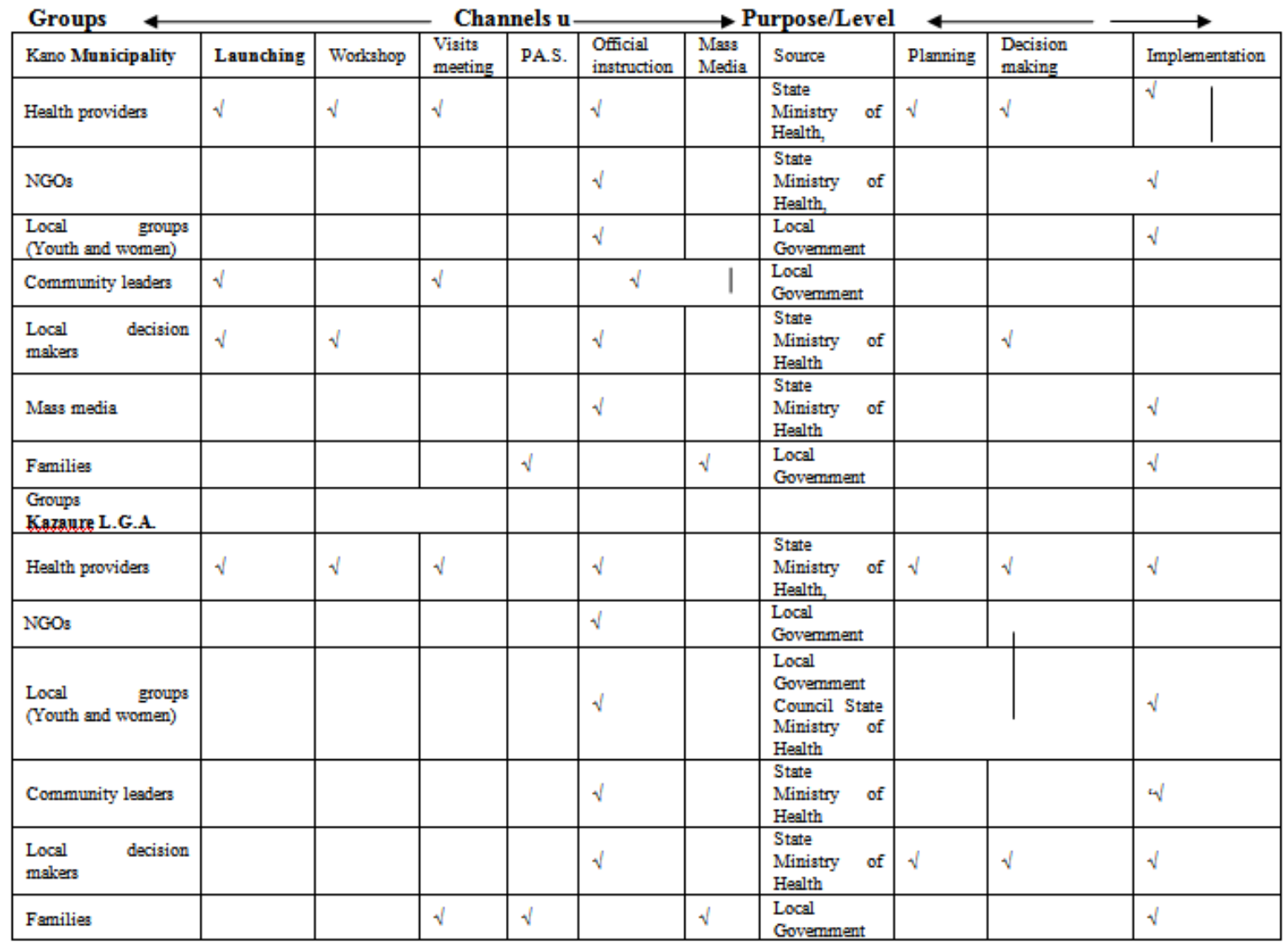

Table 4d: Communication Channels used to ensure the involvement and participation of groups at the Local Government Level in Imo State

\begin{tabular}{|c|c|c|c|c|c|c|c|c|c|c|}
\hline $\begin{array}{l}\text { Groups } \\
\text { Qgxerri L.G.A. }\end{array}$ & Lsunching & Workshop & $\begin{array}{l}\text { Visits } \\
\text { metting }\end{array}$ & P.A.S. & $\begin{array}{l}\text { Official } \\
\text { instruction }\end{array}$ & \begin{tabular}{|l|} 
Mass \\
Media
\end{tabular} & Source & Planning & $\begin{array}{l}\text { Decision } \\
\text { Making }\end{array}$ & implementation \\
\hline Health providers & & & $\sqrt{1}$ & & $\sqrt{1}$ & & State Ministry of Health, & $\sqrt{1}$ & $\sqrt{1}$ & $\sqrt{1}$ \\
\hline $\mathrm{NGOs}$ & & & $\sqrt{ }$ & & & & State Ministry of Health, & & & $\sqrt{1}$ \\
\hline $\begin{array}{l}\text { Local groups/ Youth } \\
\text { and women }\end{array}$ & & $\sqrt{ }$ & $\sqrt{ }$ & & & & L.G.A. Chaiman & & & \\
\hline Community lesders & & & & & $\sqrt{1}$ & & L.GA. Chaiman & & & $\sqrt{1}$ \\
\hline Local decision makers & & & $\sqrt{1}$ & & \multicolumn{2}{|l|}{$\sqrt{1}$} & \multicolumn{2}{|l|}{ LGA, Chaiman } & & $\sqrt{1}$ \\
\hline Families & & & $\sqrt{ }$ & & & $\sqrt{4}$ & L.GA. Chaiman & & & $\sqrt{1}$ \\
\hline $\begin{array}{l}\text { Groups } \\
\text { Ideato L.G.A. }\end{array}$ & & & & & & & & & & \\
\hline Health providers & $\sqrt{1}$ & & $\sqrt{1}$ & & & & State Ministry of Health, & $\sqrt{1}$ & & $\sqrt{1}$ \\
\hline $\mathrm{NGO}_{3}$ & $\sqrt{ }$ & & $\sqrt{ }$ & & & & LGA. Chaiman & & & $\sqrt{ }$ \\
\hline Local groups/Youth & $\sqrt{ }$ & & $\sqrt{ }$ & & $\sqrt{ }$ & & $\begin{array}{l}\text { State Ministry of Social } \\
\text { Development }\end{array}$ & & & $\sqrt{ }$ \\
\hline Community leaders & $\sqrt{ }$ & & & & $\sqrt{ }$ & & \begin{tabular}{|l|} 
L.G,A. Chaiman \\
Govemor's Office
\end{tabular} & & & $\sqrt{ }$ \\
\hline Local decision makers & $\sqrt{1}$ & & $\sqrt{1}$ & & $\sqrt{1}$ & & State Gort. & & & $\checkmark$ \\
\hline Frmilies & & & $\sqrt{ }$ & $\sqrt{1}$ & & $\sqrt{1}$ & LGA. Chaiman & & & $\sqrt{1}$ \\
\hline
\end{tabular}

2. Strategies used to ensure the involvement and participation of specific groups at the local level

Table 5 shows the strategies used to identify and reach specific groups who require education and information on the immunization programme in Kano, Kazaure, Owerri and Ideato LGAs. The 
specific groups include policy and decision makers, implementers, users (rural and urban mothers) and defaulters. The strategies used include: Mass media, Interpersonal channels, Traditional media and mass campaign

The breakdown below shows the specific strategies used to reach each of the groups.

(NIDs).

\section{Groups: Strategies/Channels Used}

Policy makersTelevision, radio, newspapers, official letters, mass campaign (NIDs) Implementers:

Television, radio, print, official letters, clinics, mass campaign, training.

Users (i) Urban mothers Television, radio, print media, clinics, traditional leaders, church leaders, baby tracking, outreach, women groups, mass campaign (NIDs)

Users (ii) Rural mothers Religious leaders, traditional leaders, market days, youth groups, women groups, campaign, children, outreach, static posts.

Defaulters Clinics, baby tracking, mass campaign (NIDs)

Table 5: Strategies used to identify and reach specific groups that require education on Immunization

\begin{tabular}{|c|c|c|c|c|c|c|c|c|c|c|c|c|c|c|c|c|}
\hline \multirow{2}{*}{$\begin{array}{l}\text { Community } \\
\\
\text { Kano } \\
\text { Municipality }\end{array}$} & \multicolumn{3}{|c|}{$\begin{array}{l}\text { Mass Media } \\
\text { - Channels }\end{array}$} & \multicolumn{11}{|c|}{ Interpersonal Channels } & \multirow{2}{*}{$\begin{array}{l}\begin{array}{l}\text { Tradit } \\
\text { ional } \\
\text { media }\end{array} \\
\begin{array}{l}\text { Town } \\
\text { criers }\end{array}\end{array}$} & \multirow{2}{*}{$\begin{array}{l}\begin{array}{l}\text { Cam } \\
\text { paign }\end{array} \\
\text { NIDS }\end{array}$} \\
\hline & $\begin{array}{l}\mathrm{T} \\
\mathrm{V}\end{array}$ & $\begin{array}{l}\mathrm{Ra} \\
\text { dio }\end{array}$ & $\begin{array}{l}P r \\
\text { in } \\
t\end{array}$ & $\begin{array}{l}\text { Offi } \\
\text { cial } \\
\text { lett } \\
\text { ers }\end{array}$ & $\begin{array}{l}\mathrm{Cl} \\
\text { ini } \\
\mathrm{c}\end{array}$ & $\begin{array}{l}\text { Ba } \\
\text { by } \\
\text { trac } \\
\text { kin } \\
\mathrm{g}\end{array}$ & $\begin{array}{l}\text { Opi } \\
\text { ni } \\
\text { on } \\
\text { lea } \\
\text { de } \\
\text { rs }\end{array}$ & \begin{tabular}{|l} 
Y \\
o \\
ut \\
h \\
Gro \\
up \\
s
\end{tabular} & $\begin{array}{l}\text { Tradi } \\
\text { tiona } \\
1 \\
\text { leade } \\
\text { rs }\end{array}$ & $\begin{array}{l}\text { Reli } \\
\text { giou } \\
\text { s } \\
\text { lead } \\
\text { ers }\end{array}$ & $\begin{array}{l}\text { M } \\
\text { ar } \\
\text { ket } \\
\text { da } \\
\text { ys }\end{array}$ & $\begin{array}{l}\mathrm{W} \\
\mathrm{o} \\
\mathrm{me} \\
\mathrm{n} \\
\mathrm{gr} \\
\mathrm{ou} \\
\mathrm{ps}\end{array}$ & $\begin{array}{l}\text { Trai } \\
\text { ning } \\
\text { wor } \\
\text { ksho } \\
\text { p }\end{array}$ & $\begin{array}{l}\text { Outr } \\
\text { each }\end{array}$ & & \\
\hline $\begin{array}{l}\text { Policy/Decisio } \\
\mathrm{n} \text { makers }\end{array}$ & $\sqrt{ }$ & $\sqrt{ }$ & $\sqrt{ }$ & $\sqrt{ }$ & & & & & & & & & & & & $\sqrt{ }$ \\
\hline Implementers & $\sqrt{ }$ & $\sqrt{ }$ & $\sqrt{ }$ & $\sqrt{ }$ & $\sqrt{ }$ & & & & & & & & $\sqrt{ }$ & & & $\sqrt{ }$ \\
\hline $\begin{array}{l}\begin{array}{l}\text { Users } \\
\text { (mothers) }\end{array} \\
\end{array}$ & $\sqrt{ }$ & $\sqrt{ }$ & $\sqrt{ }$ & & $\sqrt{ }$ & $\sqrt{ }$ & & & $\sqrt{ }$ & $\sqrt{ }$ & & & & & & $\sqrt{ }$ \\
\hline Defaulters & & & & & $\sqrt{ }$ & $\sqrt{ }$ & & & & & & & & & & $\sqrt{ }$ \\
\hline Kazaure LGA & & & & & & & & & & & & & & & & $\sqrt{ }$ \\
\hline $\begin{array}{l}\text { Policy/Decisio } \\
\mathrm{n} \text { makers }\end{array}$ & $\sqrt{ }$ & $\sqrt{ }$ & $\sqrt{ }$ & & & & & & & & & & & & & $\sqrt{ }$ \\
\hline Implementers & $\sqrt{ }$ & $\sqrt{ }$ & $\sqrt{ }$ & $\sqrt{ }$ & & & & & & & & & & & & $\sqrt{ }$ \\
\hline $\begin{array}{l}\text { Users } \\
\text { (Urban/rural) }\end{array}$ & & & & $\sqrt{ }$ & & & & $\sqrt{ }$ & $\sqrt{ }$ & & & & & & $\sqrt{ }$ & $\sqrt{ }$ \\
\hline Defaulters & & & & & & & & & & & & & & & & $\sqrt{ }$ \\
\hline Owerri LGA & & & & & & & & & & & & & & & & $\sqrt{ }$ \\
\hline $\begin{array}{l}\text { Policy/Decisio } \\
\mathrm{n} \text { makers }\end{array}$ & $\sqrt{ }$ & $\sqrt{ }$ & $\sqrt{ }$ & $\sqrt{ }$ & & & & & & & & & & & & $\sqrt{ }$ \\
\hline Implementers & $\sqrt{ }$ & $\sqrt{ }$ & $\sqrt{ }$ & $\sqrt{ }$ & $\sqrt{ }$ & & $\sqrt{ }$ & $\sqrt{ }$ & $\sqrt{ }$ & & & & $\sqrt{ }$ & & & $\sqrt{ }$ \\
\hline $\begin{array}{l}\text { Users } \\
\text { (Urban/rural) }\end{array}$ & $\sqrt{ }$ & $\sqrt{ }$ & $\sqrt{ }$ & & $\sqrt{ }$ & & & & & & & & & $\sqrt{ }$ & & $\sqrt{ }$ \\
\hline Defaulters & & & & & $\sqrt{ }$ & & & & & & & & & & & $\sqrt{ }$ \\
\hline Ideato LGA & & & & & & & & & & & & & & & & $\sqrt{ }$ \\
\hline $\begin{array}{l}\text { Policy/Decisio } \\
\mathrm{n} \text { makers }\end{array}$ & & & & $\sqrt{ }$ & & & & & & & & & & & & $\sqrt{ }$ \\
\hline Implementers & & & & $\sqrt{ }$ & $\sqrt{ }$ & & & & & & & & $\sqrt{ }$ & & & $\sqrt{ }$ \\
\hline $\begin{array}{l}\text { Users } \\
\text { (Urban/Rural) }\end{array}$ & & & & & $\sqrt{ }$ & $\sqrt{ }$ & $\sqrt{ }$ & $\sqrt{ }$ & $\sqrt{ }$ & $\sqrt{ }$ & & $\sqrt{ }$ & & & $\sqrt{ }$ & $\sqrt{ }$ \\
\hline Defaulters & & & & & & & & & & & & & & & & $\sqrt{ }$ \\
\hline
\end{tabular}

3. Steps taken to organize the people to act on the immunization messages and their motivation to participate in the programme.

In order to answer this broad question, the following specific questions have been asked. a. What actions are taken at the administrative level?

Tables $4 \mathrm{a}, 4 \mathrm{~b}$ and $4 \mathrm{c}$ show the level of political declaration and commitment at the federal, state and local government levels. At the federal and state levels, there are official declarations through official launchings. Only one local government, (Ideato local government) launched the programme officially. Administrative commitment was weak at the local government level.

\section{b. What Print and Graphic Materials are Used?}

At the federal level, brochures were available to health workers and mass media personnel, but they were riot available to opinion leaders, decision makers and mothers. Posters were available to all groups including mothers, opinion leaders, decision makers and students but flipcharts were not available to any group. 
At the state level, only posters were available. These posters were available to policy and decision makers, mass media personnel and health workers in the urban areas. They were not available in the rural areas. Where they were available in rural areas, they were found only in the clinics. Flipcharts, brochures and calendars were not available at the state level, not to talk of the local government areas.

c. Are Peoples' current knowledge, attitudes and practices concerning immunization assessed, messages and educational motivational materials pretested before production and distribution? There was no form of formative research to assess the communities' knowledge, attitudes and practices (KAP) concerning immunization before designing, producing and disseminating immunization messages to the target population. This is the situation at the federal as well as the state levels. However, some audiovisual materials on immunization were produced and distributed without pretesting with the target audiences. During the campaign, these messages met with some resistances. In all cases, (federal and state) these messages were later evaluated and modified. For instance, the rumour linking immunization with sterility was a major blow to the credibility of the programme and it had to be counteracted and clarified.

d. What training and manpower development opportunities are provided to health workers? Training opportunities were available to health workers at the federal and state levels. There were five categories of health staff that benefited from training programmes. They include: NPI Managers, Health Educators, Vaccinators, Nurses and Record keepers.

The training focused on social mobilization, cold chain technology, record keeping and steam sterilization. Nurses, Health Educators and NPI managers, except record keepers benefited from the social mobilization and steam sterilization workshops, while the vaccinators and NPI managers benefited from the training in cold chain technology and steam sterilization. In Imo state, however, nurses were not trained on social mobilization techniques and cold chain technology.

4. What are the Gaps in the Communication Strategies used during the campaign (NIDs)?

The gaps in the communication strategies used were revealed in statements an observations made by policy and decision makers, health providers, donor agencies, NGOs, media personnel, youth groups, women groups, community leaders and women during the assessment of the campaign. These gaps as identified by Implementers, decision makers and users can be treated under 10 broad categories.

i. Lack of audience segmentation.

"There was no urban-rural segmentation in the design and chanelling of immunization messages" (UNICEF)

ii. Poor message design and saliency

"There were no messages to convey the number of visits to the clinic and when to come back. The facts of the side effects were not addressed. Mothers were not told what to do" (UNICEF).

iii. Source credibility.

"Sometimes, we used unpopular and controversial traditional rulers as channels for informing the grassroot population. But once the people do not accept a leader, they will not accept messages coming from him" (LGA official, Owerri).

iv. Lack of Interpersonal reinforcement of media messages at the community level.

"The campaign merely informed people to come out for immunization. They did not have face to face discussions with mothers, chiefs and children" (Scout Leader, Ideato).

"I did not immunize my child against measles because my child was sick and I suspected measles... there was no body to advise me on what to do". (Mother, Ozu Community, Ideato).

"In the urban areas, there are no community-based contacts between health workers and the community to reinforce messages heard on radio or television. All outreach efforts are in rural areas". (Sheik Aminu El Kanamy, Kano).

v. Lack of Incentives attached to messages.

"There were no incentives to motivate mothers... mothers time wasted was not acknowledged and addressed". (UNICEF).

vii. Media of Communication

"Media of communication for the NPI is limited to the NIDs when the Emir goes to the rural areas and

the people come out. It should be continuous". (Director, Agency for Mass Education, Kano). "People do not believe in jingles but react to last minute mobilization. That is the psychology of the people" (Information Officer, Owerri LGA)

viii. Poor Interpersonal Communication Skills.

The concept of training of health staff, volunteer workers and extensionists is not purposeful, but limited to information giving. Those trained do not and cannot mobilize" (UNICEF). 


\section{ix. Poor Information Management}

"Some mothers who participated in the National Immunization Days (NIDs) campaign did not come back because they did not link NIDs with routine (NPI) immunization" (Women Group, Ideato, Imo State).

'Some mothers interviewed did not know what their children had been given or when to return for further vaccination (NPI manager, Imo State).

"The date for the National Immunization Days (NIDs) campaign was shifted and people were not informed about the new date. This affected the turn out rate" (Director, Murtala Mohammed Hospital, Kano).

x. Lack of Research and Pretesting

"There was no form of formative research to assess the communities' knowledge, attitudes and practices concerning immunization before designing, producing and disseminating immunization messages to the target population. At the federal and state levels, audiovisual materials were produced and distributed without pretesting. During the campaign, these messages met with some resistance". (UNICEF Report). $x$. Lack of Decentralization

"The planning of the campaign takes place at the federal level. It filtered down to the states and from the states to the local government areas... before the message got through these layers, it was foggy" (UNICEF).

\section{Discussion of Findings}

The findings show that there is a high level of political commitment to the programme by policy and decision makers at the three tiers of government as demonstrated by the launchings at the federal and state levels. However, this is not necessarily so at the local government and municipal levels. There is a high level of collaboration between health workers and non-health workers, community leaders, women groups, youth groups. Non-Governmental Organizations and other sectors in the implementation of the programme, with the education and information sectors more involved. However, the level of collaboration declines as one moves from the federal to the states and the local government levels.

The communication channels used to ensure the involvement and participation of health workers, NGOs, local groups, community leaders and deóision makers include both mass media and interpersonal channels at the federal and state government levels and mainly interpersonal channels at the local government level. Community leaders and community groups were involved in the progranune through official launchings, meetings, workshops and official letters from the federal and state government functionaries. At the local government level however, the channels used are largely interpersonal. As for mothers, the communication channels used include, clinic based health education, baby tracking, community based health campaigns, use of traditional leaders, churches, mosques and school announcements, use of school children, youth and women groups, posters, radio spot announcements and jingles.

The strategies used to identify and reach specific groups that required education and information on the immunization campaign (NPI) show that policy makers were reached through radio, television, newspapers, official letters, and mass campaigns. On the other hand, the implementers of the immunization campaigns were reached through mass media, clinics, workshops and mass campaigns.

Rural mothers unreached by the mass media were reached through traditional leaders, market days strategy, religious leaders, youth groups, outreach by health workers, static posts and mass campaigns. The defaulting mothers were however reached at the clinics, through baby tracking by youth groups and mass campaigns (NIDs).

Several steps were also taken at various levels to organize the people to act. These steps include political declaration by the Federal and State governments. The local government areas (except Ideato LGA) did not make any political declarations. In addition, simple brochures and posters were made available to health and media personnel at the federal level. At the state and local community levels, these information materials were not available in the clinics and in the community.

There is no indication that programme planners conducted surveys to assess community knowledge, attitudes, and practices concerning NPI nor have messages designed been pretested with the user community before production and dissemination at all levels. But efforts have been made to evaluate message impact on the target population with a view to modifying messages and selecting channels that are appropriate. In order to strengthen staff capabilities, there were also opportunities provided for health workers to upgrade their skills through seminars and workshops which focused on record keeping, social mobilization and cold chain maintenance. In the course of the study, certain gaps in the communication strategies used in the campaign were identified. The gaps include, lack of audience segmentation and targeting, poor message content, lack of source credibility and interpersonal reinforcement, lack of incentives, poor interpersonal communication skills and information management by health workers and lack of research and decentralization of planning and services. 


\section{Summary}

From what this study has revealed, the mass campaigns (NIDs) engendered the collaboration and support of community leaders, professional groups, social groups and other sectors with health workers. It aroused the community's social system to action and transcended sectoral, organizational and environmental barriers. Where the support was inadequate or lacking, the health workers were incapacitated. This reaffirms our assumption that the success of social campaigns is not only a matter of government capabilities, but also how those capabilities are used. The more partners, the more effective the campaign. The communication strategies used for the campaign show that the alliance between the information and education sectors and health for child survival was beneficial. It helped with programme promotion and advocacy. For the first time, an attempt was made to institutionalize and integrate NPI messages with formal media.

Media personnel were trained in NPI message design and feedback mechanisms, and broadcast media programmes were reinforced with brochures, posters and community-based interpersonal inputs by health workers in order to get the people involved. However, these channels were not effectively used at the local level where the people need them most. The significant role of the traditional media cannot be overlooked when considering the legitimization of NPI messages. The use of community-based information network of traditional leaders, opinion leaders and gatekeepers helped to break down community resistance to NPI messages. Under such circumstances, message source becomes more important to the audience than the messages themselves, especially when such messages concern an innovation. The findings seem to fit the assumption, that in the diffusion of innovation for child survival, the opinion leaders and early adopters should be used to motivate potential adopters. The acceptance of innovation message is facilitated when it is mediated by credible time tested and influential opinion leaders.

In order to organize the people to act on the NPI messages they gain, federal and state governments launched the programme. By launching the programme, it became a political agenda for child survival. It was found that the messages developed by health workers and media personnel are not salient because they are not based on audience needs. Without audience research and pretesting, messages disseminated lacked content and relevance. They did not address mothers' fears and constraints. In the absence of audience analysis, the audiences were not segmented and messages were not streamlined and localized. The implication of this is that planners never understood resistances inevitably aroused by their messages. This shows that campaign planners and implementers lack the skills to relate to the people on a give and take basis and this can lead to unequal and dependency relationships between the source and users and eventual demise of the programme.

\section{References}

[1] Brown, L.(1981). Innovation Diffusion: A New Perspective. New York; Methuen and Co. Ltd, Publishers.

[2] Freire, Paulo, (1973). Education for Critical Consciousness. New York: Seabury Press.

[3] Green, L. (1983). "New Policies for Health Education in Primary Health Care". Geneva, WHO. Background Papers for World Health Assembly.

[4] Green, L. and McLister, A. (1984). "Macrointerventions to Support Health Behaviour: Some Theoretical Perspectives and Practical Reflections" Health Education Quarterly. Vol. 11. pp. 332-339.

[5] Hall, B. (1978). "MTU NI AFYA": Tanzania Health Campaign, Washington D.C. Academy for Educational Development.

[6] Hubley, J. (1986). "Barriers to Health Education in Developing Countries". Health Education Research. Vol. 1, No. 6, Pp.233-245.

[7] Imoh, G. (1986). "An Evaluation of the Communication Strategies used for NPI". Unpublished MA Thesis, Department of Communication and Language Arts, University of Ibadan.

[8] Imoh, G. (1991). "Communication for Social Mobilization: An Evaluation of EPI in Nigeria" Unpublished Doctoral Thesis, University of Ibadan.

[9] James, S. (1986). "Preparing Audiences to Receive Media Messages on Rural Development". Africa Media Review. Vol. 1, No.

[10] Mburu, F. (1977). Traditional versus Modem Medicine in Africa”. In Singer, P. (ed). Traditional Healing: New Science or New Colonialism. Couch Magazine Ltd, Publishers, Owerri.

[11] Nwosu, 1. (1986). "Mobilizing Peoples' Support for Development: An Analysis of Public Enlightenment Campaigns in Africa". Africa Media Review. Vol. 1, No. 1. p.49.

[12] Owens-Ibie, N. (2002). "Communicating Health Issues in Nigeria: Challenges for Immunization Activities" in Lai Oso (ed.) Communication and Development: A Reader. Abeokuta Jedidaiah Publishers, p.229.

[13] Postgate, R. and Peter L. (1977). "Communication for the Individual and Extension of Choice" Paper presented at the Annual Conference of the International Institute of Communication, Washington, D.C.

[14] UNICEF: The State of the World Children Report: 2003.

[15] Wesley, B. and Maclean, M. (1984). “A Conceptual Model of Communication Research”. Journalism Quarterly. Vol. 34.pp.31-38.

[16] World Health Organization (1981). Development of Indicators for Monitoring Programme towards Health for All by 2000 AD. Geneva, No.3.

[17] World Health Organization (2003). The Immunization Programme in Nigeria. Geneva. 